\title{
Ecological productivity of Lake Tinishu Abaya in relation to photosynthetic productivity and biomass of phytoplankton, Rift Valley, Ethiopia
}

\begin{abstract}
The present study was undertaken to investigate the photosynthetic productivity and biomass of phytoplankton with respect to changes in various physicochemical factors for Lake Tinishu Abaya (Ethiopia) to observe the potentiality of the lake water for fish production and other multiple designated water uses. The study was carried out for a year from January to December 2016. For the analysis of various physicochemical parameters, water samples collection was taken from two pre defined sampling stations (open-water and near shore). Biomass of phytoplankton was measured as concentration of chlorophyll a. Primary productivity of phytoplankton was measured at the open station in the euphotic depth using light-dark bottle technique with measuring $\mathrm{O}_{2}$ concentration and its value was converted to carbon contents. It was observed from the results that the light-saturated rate of photosynthesis $\left(\mathrm{A}_{\max }\right)$, ranged from $0.62 \mathrm{~g} \mathrm{C} \mathrm{m}^{-3} \mathrm{~h}^{-1}$ to $2.02 \mathrm{~g} \mathrm{C} \mathrm{m}^{-3} \mathrm{~h}^{-1}$ and Biomassspecific rate of photosynthetic productivity at light saturation $\left(\mathrm{P}_{\max }\right)$ ranged from 0.02

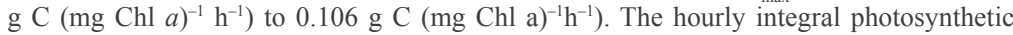
production $\left(\sum \mathrm{A}\right)$, varied between $0.247 \mathrm{~g} \mathrm{C} \mathrm{m}^{-2} \mathrm{~h}^{-1}$ and $1.022 \mathrm{~g} \mathrm{C} \mathrm{m}^{-2} \mathrm{~h}^{-1}$, whereas the calculated pattern of variation for the daily integral rates of photosynthesis $(\Sigma \Sigma \mathrm{A})$ values was ranged from a minimum of $5.43 \mathrm{~g} \mathrm{C} \mathrm{m}^{-2} \mathrm{~d}^{-1}$ to a maximum of $9.194 \mathrm{~g} \mathrm{C} \mathrm{m}^{-2} \mathrm{~d}^{-1}$. The concentration of phytoplankton biomass (chlorophyll-a) was varied from a minimum of $18.97 \mathrm{mg} / \mathrm{L}$ to a maximum of $65.05 \mathrm{mg} / \mathrm{L}$. The various physicochemical factors responsible for the observed temporal variations in the physical, chemical and biological features of the lake are discussed and generalized that the lake water was well oxygenated, slightly warm, alkaline, contained more TSS, and EC, very turbid and low transparency. The lake water was fresh based on TDS value. Most of the inorganic nutrients were relatively higher and supports most aquatic lives. Based on the results of the study on various physicochemical factors, photosynthetic productivity and biomass of phytoplankton, it was concluded that the water of Lake Tinishu Abaya was a productive which supports the life of most aquatic lives, production of fish, and other related multidimensional uses.
\end{abstract}

Keywords: biomass, Photosynthetic productivity, physicochemical factors, phytoplankton, light-dark bottle technique
Volume 3 Issue 4 - 2018

\author{
Yirga Enawgaw, Brook Lemma \\ Department of Zoological Sciences, College of Natural and \\ Computational Sciences, Addis Ababa University, Ethiopia
}

Correspondence: Yirga Enawgaw, Department of Zoological Sciences, College of Natural and Computational Sciences, Addis Ababa University, P.O. Box. I 176, Addis Ababa, Ethiopia, Email yirgaenawgaw@yahoo.com

Received: May 23, 2018 | Published: August 20, 2018

\section{Introduction}

Studies on primary production by phytoplankton are essential for understanding energy and material flows in pelagic ecosystems. ${ }^{1}$ As phytoplankton assemblages are at the base of the food web, changes in phytoplankton biomass and pattern of primary production have implications for the whole community, including fish. ${ }^{2}$ For instance, phytoplankton production (PP) is regarded as a good predictor of fish yield in lakes and seasonal measurements of PP are a prerequisite for good such estimates. ${ }^{3}$ The primary productivity of different water bodies has been widely investigated to assess the fish production potentialities of a water body to formulate appropriate fishery management policies. The growth of a fish is influenced by the quality and quantity of food material available and consumed. Thus, any variation in quality and quantity of food materials will affect the growth rate of the fish. ${ }^{1}$ Primary productivity of various water bodies has been studied by several workers in order to predict their fish production potential and to formulate fishery management policies. In order to meet the growing food requirements of the world population, great effort is needed in the development and utilization of the biological wealth of the aquatic environment. ${ }^{4}$ The study of energy transfer in lakes and reservoirs is based on the measurement of primary productivity of phytoplankton and the environmental variables, which limit or control this productivity. Primary productivity of aquatic ecosystems is basically dependent upon the photosynthetic activity of autotrophic organisms. ${ }^{5}$

Primary productivity and biomass of phytoplankton are affected by an array of chemical, physical, and biological factors. There is no doubt that in general, the more frequently a lake is stirred by winds to the bottom, the faster the nutrients are recycled from the mud into the photosynthetic zone where they may accelerate the rate of productivity. ${ }^{6}$ The dynamics of phytoplankton standing stock and productivity in African lakes was reported to vary intimately with the fluctuation in water. ${ }^{7}$ The various nutrients required by algal cells for growth and multiplication may not always be found in relative proportions required by phytoplankton rather phosphorous and nitrogen in all groups and silicon in diatoms are regarded as growth limiting nutrients. ${ }^{8}$ Limnological studies of tropical freshwater ecosystems are not extensive when compared to temperate ones; nevertheless East African lakes have been studied fairly well in comparison with other regions of Africa. Hecky ${ }^{9}$ noted that East African lakes are regarded as among the world's most productive ecosystems. Ethiopia is endowed with a large number of standing water bodies, whose sustainable use can contribute to the economy of the country. The lakes are critical to 
the survival of local communities as they are the actual and potential sources of food and income. Despite their importance, the limnology of some of the Ethiopian lakes is unexplored. Lake Tinishu Abaya is one of such lakes, which has not received attention in spite of its potential economic importance. Lake Tinishu Abaya has a lot of functions (including fish production) for the local community. However, there has not been any planned research activity has conducted on it. This is maybe predominantly due to its remote location and having small size that made it considered insignificant as compared to other large rift valley lakes of Ethiopia. The purpose of this study was, therefore, to investigate the photosynthetic productivity and biomass of phytoplankton in relation to various physicochemical variables of Lake Tinishu Abaya (Ethiopia) to observe the potential of the lake water productivity for fish production and other related multiple designated water uses.

\section{Materials and methods}

\section{Study area}

Lake Tinshu Abaya, which is interchangeably called Small Abaya to imply its size and to separate the other large lake (L. Abaya) having similar name of Tinishu Abaya, is located at about $160 \mathrm{~km}$ Southwest of Addis Ababa, capital city of Ethiopia. It is situated in the Silttie Zone (Silttie District, Kebet/Silttie Town) of the Southern Nations, Nationalities and Peoples Regional State of Ethiopia. It is found in a small village termed Gebrie-Ber located at about $15 \mathrm{~km}$ in the eastern direction from the town of Kebet/Silttie. The lake is located at $7^{0} 29^{\prime} 03.65^{\prime \prime} \mathrm{N}$ latitude and $38^{\circ} 03^{\prime} 17.79^{\prime \prime} \mathrm{E}$ longitude and at an altitude of $1835 \mathrm{~m}$ above sea level. Lake Tinishu Abaya is a small-sized inland freshwater system among the rift valley lakes of Ethiopia. The lake covers a total area of 1253 hectares $\left(12.53 \mathrm{~km}^{2}\right) .{ }^{9} \mathrm{It}$ is a shallow lake with a maximum and a mean depth of $3.7 \mathrm{~m}$ and 2.9 $\mathrm{m}$ respectively (survey of this study). The lake is almost an oval shape (Figure 1). Lake Tinishu Abaya has two feeder rivers and a single outlet. Rivers Dacha (northern corned) and Boboda (southern corner) are the main tributaries for the Lake Tinishu Abaya. River Badober (northern corner) is a small river which served as an outlet for the lake. During this study, two major perennial rivers (Rivers Dacha and Boboda) and a single outlet (River Badober) were always active.

The lake has some commercially important fish species including Nile tilapia (Oreiochromis niloticus), Tilapia zillii and Barbus species. Barbus sp. and T. zillii are native for the lake whilst $O$. niloticus was stock from the nearby rift valley Lake Ziway (Ethiopian) in $1997 .{ }^{10}$ O. niloticus in Lake Tinishu Abaya was found to be an omnivorous fish mainly feeding on phytoplankton, detritus and macrophytes. In addition, zooplankton and insects constituted minor portion of the diet of O. niloticus in Lake Tinishu Abaya. ${ }^{11}$ According to Yirga ${ }^{12}$ the major phytoplankton taxa which was identified in Lake Tinishu Abaya includes Bacillarophyta (15 species), Chlorophyta (11 species), Cyanobacteria (7 species), Euglenophyta (2 species), Dinophyta (1 specie), and Cryptophyta (1 species). The zooplankton communities which were found in Lake Tinishu Abaya were the large-sized crustaceans (copepods and cladocerans) and the smaller rotifers. ${ }^{13}$ Rotifers had the highest number of species (11 species) followed by cladocerans ( 5 species) and copepods ( 2 species).

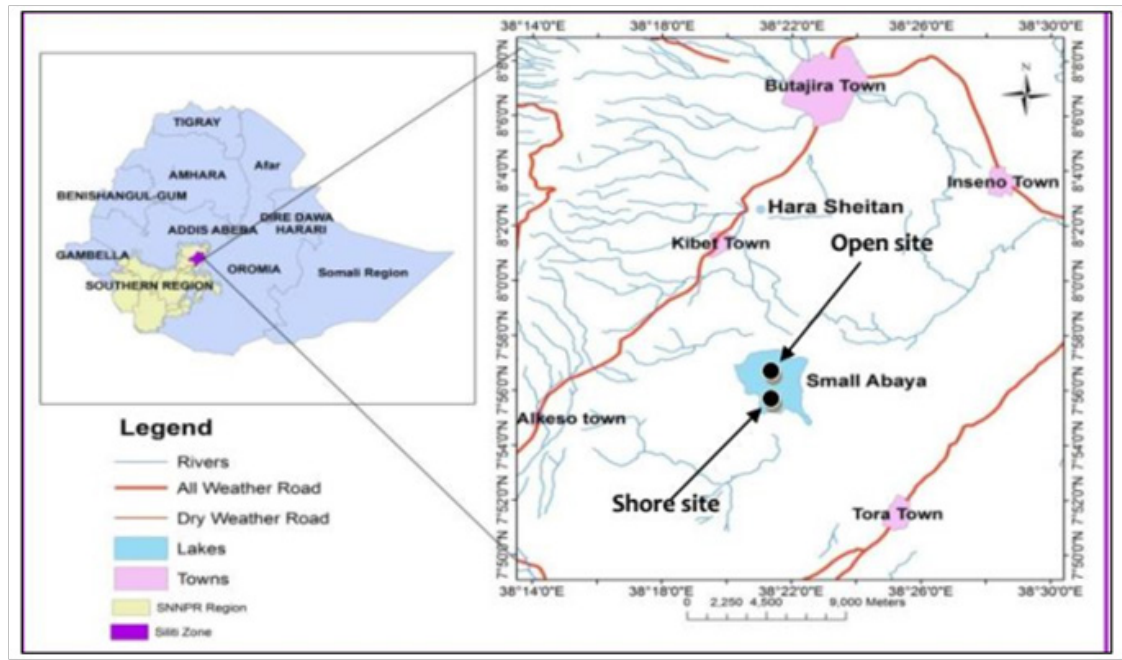

Figure I Location of Lake Tinishu Abaya represented in this map as Small Abaya and sampling sites.

\section{Sampling protocol}

For physicochemical measurements, routine water sample collections were carried out on a monthly basis between January 2016 and December 2016 from two pre defined sampling stations, one from an area of high human impact (offshore station-SS: $07^{\circ} 57.234^{\prime} \mathrm{N}$ \& 03822.037 'E at elevation of $1822 \mathrm{~m}$ ) and the second was from a relatively less human impacted area (open-water station-OS: $07^{0}$ $56.658^{\prime} \mathrm{N} \& 038^{\circ} 21.787^{\prime} \mathrm{E}$ at elevation of $1822 \mathrm{~m}$ ). The open-water site is located on the center of the lake while offshore site is located nearly $50 \mathrm{~m}$ far from the shoreline of the lake. The open- water site is relatively protected from the direct human impacts. The wastes from their domestic animals such as cattle and related agricultural byproducts cannot easily enter and reach the open-water site especially in dry season where no flood to carries the waste matter from the watershed; and hence the site is considered relatively protected from human impacts. On the other hand, the offshore site is so close to the edge of the lake (no buffering zone) and this site is considered as a direct recipient of wastes from agricultural land as well as domestic materials; thus this site was taking into consideration as impaired by human activities compared to open-water site. From the two sampling sites, water samples were collected from selected depths distributed 
within the euphotic zone. The samples collected from different depths were mixed in equal proportions to produce a composite sample for measurement of biomass (Chlorophyll a) concentration. Each water sample chilled in icebox on site and transported to the limnology laboratory of Addis Ababa University for further analysis.

\section{Measurement of physicochemical parameters}

In-situ measurements for the parameters temperature, dissolved oxygen (percentage saturation), conductivity and $\mathrm{pH}$ was measured using a portable multi-meter (Model HQ 40d Multi Hach Lange) and water transparency was measured using a standard Secchi disc having $30 \mathrm{~cm}$ in diameter. The euphotic depth (Zeu), the depth at which $1 \%$ of the surface photosynthetic active radiation is detected, for the study area, was calculated from the relation Zeu $=4.6 / \mathrm{Kd}^{14}$ Extinction coefficient $(\mathrm{Kd})$ was found from Secchi disk $(\mathrm{Sd})$ relationship of Holmes $^{15}$ formula as $\mathrm{Kd}=1.44 / \mathrm{Sd}$. Turbidity was measured using portable digital turbid meter (Model OAKTON: T-100). In the Laboratory, total suspended solids (TSS) and total dissolved solid (TDS) were determined through the standardized gravimetric method for examination of TSS and TDS in water analysis by Howard 1933. TSS was measured by filtering $100 \mathrm{ml}$ of water using Whatman GF/F glass microfiber filters (Diameter: $47 \mathrm{~mm}$; Model PB-1825-047-BR) and dried at $105^{\circ} \mathrm{C}$ for 2 hours. Then, weighted with suspended solid and subtract the dried Weight from the Weight of the GF/F fiber and this was divided by the volume of filtered water. A similar procedure was followed for the determination of TDS. The major dissolved inorganic nutrients were determined using standard method of APHA $^{16}$ (Table 1).

Table I Standard method ${ }^{18}$ for the determination of inorganic nutrients

\begin{tabular}{ll}
\hline Nutrients & Method \\
\hline SRP & $\begin{array}{l}\text { Ascorbic Acid } \\
\text { Un filtered water digested using potassium- } \\
\text { peroxodisulphate, and autoclaved at I20 0C for } 50 \\
\text { minutes then follow SRP procedure }\end{array}$ \\
$\mathrm{SIO}_{2}$ & $\begin{array}{l}\text { Molybdosilicate } \\
\mathrm{NO}_{2}\end{array}$ \\
$\mathrm{NO}_{3}$ & $\begin{array}{l}\text { Reaction between sulfanilamide and N naphthyl- (I)- } \\
\text { ethylendiamin dihydrochloride }\end{array}$ \\
$\mathrm{NH}_{4}$ & Sodiumsalicylate \\
\hline
\end{tabular}

Measurement of biomass (chlorophyll a) and primary productivity

Biomass of phytoplankton for the study lake was estimated as chlorophyll- $a$ content. For Chl- $a, 100 \mathrm{ml}$ of water samples was filtered onto duplicate Whatman GF/F glass microfiber filters $(0.7 \mathrm{~m} \mu$ pore size; $47 \mathrm{~mm}$ Diameter, Model PB-1825-047-BR) and the filters was deep-frozen overnight to facilitate extraction. Then the filters was homogenized and extracted in $90 \%$ acetone. Chl- $a$ was determined spectrophotometrically after centrifugation at $665 \mathrm{~nm}$ and $750 \mathrm{~nm}$ without phaeopigments correction. ${ }^{17}$

Primary productivity of phytoplankton was measured at the open station using light-dark bottle technique with measuring $\mathrm{O}_{2}$ concentration. ${ }^{18}$ Since the lake size is relatively small and frequently mixing, spatial variations of environmental variables are unexpected rather seasonality is more apparent on such lake. In addition the open site is relatively less turbid (good for light penetration) than shore sites; thus we considered the open site is a representative for our studying of photosynthetic activities than shore site. Winkler bottles $(250 \mathrm{ml})$ were filled with integrated water samples and were incubated at different depths (within the euphoric depth) for 3 hours. Dark bottles were kept in light-proof dark-bags and the top of the bottles were wrapped with aluminum foil. After incubation, the bottles were retrieved and immediately fixed with Winkler's reagents. The bottle transferred to laboratory in ice box and immediately the sample was acidified, well-mixed and the whole content was titrated with standard sodium Thiosulfate $(0.01 \mathrm{~N})$.

Gross and net photosynthetic rates (GP \& NP) were calculated using the formula given in Wetzel and Likens (2000). The hourly rate of gross photosynthesis per unit area $\left(\sum \mathrm{A}\right)$ estimated from depth profiles of gross photosynthesis by the Gird Enumeration Analysis. ${ }^{19}$ The daily integral rates of photosynthesis $\left(\sum \sum \mathrm{A} \mathrm{mg} \mathrm{O}_{2} \mathrm{~m}^{-2} \mathrm{~d}^{-1}\right)$ of the lake were determined from the hourly-integrated rates by multiplying with the a factor used by Talling and Talling (1965) for East African Lakes which is 0.9 . The products then multiplied by the number of hours of sunshine often considered for tropical lakes (i.e. 10). ${ }^{20}$

\section{Results}

\section{Physicochemical features}

The value of surface temperature ranged from $18.5^{\circ} \mathrm{C}$ to $27^{\circ} \mathrm{C}$ and $18.5^{\circ} \mathrm{C}$ to $29.2^{\circ} \mathrm{C}$ while surface dissolved oxygen (DO) ranged from $5.85 \mathrm{mg} / \mathrm{L}$ to $15.1 \mathrm{mg} / \mathrm{L}$ and $6.1 \mathrm{mg} / \mathrm{L}$ to $11.62 \mathrm{mg} / \mathrm{L}$ at open and shore stations respectively. The $\mathrm{pH}$ of the study lake ranged from a minimum value of 8.11 to a maximum value of 9.27 at open station and from 8.15 to 9.22 at shore station. Total alkalinity also varied from a range of $1.44-8.26 \mathrm{meq} / \mathrm{L}$ and $0.96-6.94 \mathrm{meq} / \mathrm{L}$ at open and shore station respectively. Electrical conductivity of surface water for the study lake varied from $181.1 \mu \mathrm{Scm}^{-1}$ to $1006 \mu \mathrm{Scm}^{-1}$ at open station and $147.7 \mu \mathrm{Scm}^{-1}$ to $1006 \mu \mathrm{Scm}^{-1}$ at shore station. The results of TSS ranged from $73-243 \mathrm{mgCaCO}_{3} / \mathrm{L}$ and $76-368 \mathrm{mgCaCO}_{3} / \mathrm{L}$ at open and shore stations respectively. TDS was varied from lower values of $404 \mathrm{mg} / \mathrm{L}$ at open station and $412 \mathrm{mg} / \mathrm{L}$ at shore station to the higher value of $719 \mathrm{mg} / \mathrm{L}$ and $819 \mathrm{mg} / \mathrm{L}$ at open and at shore stations respectively. Turbidity varied from 57 to 143 NTU at open station and 71 to 188 NTU shore station.

The major inorganic nutrients analyzed in the present study were nitrogen (nitrite- $\mathrm{NO}_{2}$, nitrate- $\mathrm{NO}_{3}-\mathrm{N}$ and ammnium- $\mathrm{NH}_{4}-\mathrm{N}$ ), phosphorus (soluble reactive phosphorus-SRP and total phosphorusTP) and dissolved silicate $\left(\mathrm{SiO}_{2}\right)$. The concentration of Nitrite $\left(\mathrm{NO}_{2}\right)$ ranged from $68.11 \mu \mathrm{g} / \mathrm{L}$ to $1314.18 \mu \mathrm{g} / \mathrm{L}$ and $80.98 \mu \mathrm{g} / \mathrm{L}$ to $1447.6 \mu \mathrm{g} / \mathrm{L}$ at open and shore station respectively. Nitrate $\left(\mathrm{NO}_{3}\right)$ varied from $141.8 \mu \mathrm{g} / \mathrm{L}$ to $351.44 \mu \mathrm{g} / \mathrm{L}$ at open station and $152 \mu \mathrm{g} / \mathrm{L}$ to 341.02 $\mu \mathrm{g} / \mathrm{L}$ at shore station. Ammonium nutrient $\left(\mathrm{NH}_{4}\right)$ also varied from $28.91 \mu \mathrm{g} / \mathrm{L}$ to $71 \mu \mathrm{g} / \mathrm{L}$ and $33.33 \mu \mathrm{g} / \mathrm{L}$ to $95.85 \mu \mathrm{g} / \mathrm{L}$ at open and shore station respectively. Phosphorus nutrients in the form of soluble reactive phosphorous (SRP) and total phosphorus (TP) was also investigated and the results of SRP-P varied between a minimum of $24.1 \mu \mathrm{g} / \mathrm{L}$ to a maximum of $48.13 \mu \mathrm{g} / \mathrm{L}$ and $27.83 \mu \mathrm{g} / \mathrm{L}$ to 60.17 $\mu \mathrm{g} / \mathrm{L}$ at open and shore stations respectively. The concentration of TP ranged from $56.73 \mu \mathrm{g} / \mathrm{L}$ to $285.5 \mu \mathrm{g} / \mathrm{L}$ at open station and $75.65 \mu \mathrm{g} / \mathrm{L}$ to $294.5 \mu \mathrm{g} / \mathrm{L}$ at shore station. Dissolved silica $\left(\mathrm{SiO}_{2}-\mathrm{Si}\right)$ ranged from $21 \mu \mathrm{g} / \mathrm{l}-185.67 \mu \mathrm{g} / \mathrm{L}$ and $20.99 \mu \mathrm{g} / \mathrm{l}-180.89 \mu \mathrm{g} / \mathrm{L}$ at open and shore stations respectively. As expected from a small-sized and shallow lake, and frequently mixing, temperature and dissolved oxygen more 
varied seasonally than spatially. The minimum and the maximum value of temperature observed in December and June respectively at both shore stations. Even the peak surface temperature was recorded in June; its high value was seen during the dry season (JanuaryMay). Low temperature was seen from August to September (rainy season) and it increased in October and November (dry season). The minimum value of DO was observed in May at both stations while the maximum value was observed in January at open station and in March at shore station. Generally, high value of surface DO was observed from January to March (dry season) then showed an oscillation.

$\mathrm{pH}$ showed a seasonal variation with a significant differences $(\mathrm{F}=19.049, \mathrm{P}=.000)$. The higher value of $\mathrm{pH}$ was seen during dry season than rainy season. The total alkalinity of the study lake also showed marked temporal fluctuations with higher value was seen during dry season $(\mathrm{F}=10.331, \mathrm{P}=.004)$. The minimum value of total alkalinity recorded in August at open station and in July at shore station whereas its maximum value was reported in April and January at open and shore station respectively. Generally, high value of total alkalinity observed from January to April (dry period) and low from July to September (rainy period). $\mathrm{pH}$ correlated strongly and negatively with TSS $(r=-0.468)$ whereas it correlated positively and significantly with Secchi disk $(r=0.583)$. Conductivity varied spatially and seasonally $(\mathrm{p}<0.05)$. It was higher at open-water (central) station than at the shore station. Higher value of conductivity recorded during dry (January to March) while the lower value was observed during the main rainy season (June-September). The peak value of conductivity was reported in March and January at open and shore station respectively. Conductivity was correlated negatively with TSS $(\mathrm{r}=-0.448)$ and turbidity $(\mathrm{r}=-0.443)$. TSS varied seasonally with a significant differences $(\mathrm{F}=30.79, \mathrm{P}=.000)$ in which its value was high during the rainy season. The minimum value of TSS was recorded in November at both stations while the peak value was reported in July and August at open and shore stations respectively. The lower value of TSS was observed from November to January. TSS correlated strongly but negatively with Secchi disk, Chl- $a, \mathrm{pH}$ and conductivity with Pearson Coefficient values ( $\mathrm{r}$ ) of $-0.442,-0.568,-0.468$ and -0.652 respectively. In this study, both sites have shown high amount of total dissolved solids (TDS). High values of TDS were observed in time of the rainy season (June to September) whereas the lower value was seen during dry season (January-May and November to December). Turbidity also varied seasonally with a significant differences ( $\mathrm{F}=$ $8.612, \mathrm{P}=.008$ ) and its higher value was reported during the main rainy season especially in June and July. Turbidity was also relatively high from May to December and low from January to April. Turbidity correlated positively and strongly with TSS $(\mathrm{r}=0.777), \mathrm{NO}_{2}(\mathrm{r}=0.577)$ and TP $(\mathrm{r}=0.523)$ while it correlated negatively with DO $(\mathrm{r}=-0.510)$, chlorophyll- $a(\mathrm{r}=-0.515)$ and conductivity $(\mathrm{r}=-0.443)$.

The maximum value for both nitrite and ammonium nutrients was recorded at shore station but insignificant differences $(\mathrm{P}>0.05)$. Nitrite and ammonium nutrients were more varied seasonally with higher concentrations reported during the main rainy season (June to September) and reduced in dry season (November to February). Likewise, ammonium was high in the beginning of the rainy season (April to May) and the main rainy season (June to July). However, its peak concentration was recorded in February at both stations. Unlike nitrite and ammonium nutrients, the higher value of nitrate was observed in dry season and its peak value was seen in November Phosphorus nutrients showed a significant seasonal variation $(\mathrm{p}<0.05)$. The higher SRP concentration recorded in dry season while the concentration of TP was high during the rainy season. The peak value of SRP was seen from January to March and its relative lower value was observed from June to July. A clear oscillation was observed in the concentrations of TP and it was maximum from May to July then reduced in August then after it increased again from September to October. The lower value of TP was seen in January and February. Even it was low during dry season high value of TP was observed in March. Higher dissolved silica recorded in rainy time (June to September) and the low value reported during the dry season (January to April and October to December.

\section{Depth profiles of temperature and oxygen}

In this study the depth profile of temperature and dissolved oxygen was measured. The water temperature at the deepest depth of measurement $(2.5-3 \mathrm{~m})$ at open station ranged from a minimum of $17.84^{\circ} \mathrm{C}$ at $2.5 \mathrm{~m}$ in September to a maximum of $22.5^{\circ} \mathrm{C}$ at $3 \mathrm{~m}$ in April. Temperature difference between surface and maximum depth $(2.5-3 \mathrm{~m})$ at open station was $0.1^{\circ} \mathrm{C}$ in August and $6.4^{\circ} \mathrm{C}$ in February, the latter representing the largest temperature difference between surface and maximum depth of the column of the lake water. Similarly at shore station the water temperature at the deepest depth of measurement $(1.5-2 \mathrm{~m})$ ranged from a minimum of $18.1^{\circ} \mathrm{C}$ at $1.5 \mathrm{~m}$ in December to a maximum of $25.1^{\circ} \mathrm{C}$ at $1.5 \mathrm{~m}$ in May. On the other hand, from the study of depth profiles of dissolved oxygen of Lake Tinishu Abaya, all depth profiles showed oxygen maximum in the upper layer of the water column and it declined with increasing depth. During the study period concentration of dissolved oxygen at the maximum depth $(3 \mathrm{~m})$ showed temporal variations from a minimum of $4.84 \mathrm{mg} \mathrm{O} / \mathrm{L}$ in August to a maximum of $7.32 \mathrm{mg} \mathrm{O} / \mathrm{L}$ in April at open station. Oxygen-maxima were observed between $0-0.5 \mathrm{~m}$ depths in most of the sampling months. Oxygen-maximum was found at a shallow depth near the surface (at $0.5 \mathrm{~m}$ depth) in January, February and April.

\section{Biomass (Chlorophyll-a)}

The results of changes in phytoplankton biomass measured as chlorophyll- $a$ concentration in Lake Tinishu Abaya is shown in Figure 2. The concentration of chlorophyll- $a$ value that was recorded during the study period was varied from a minimum of $18.97 \mu \mathrm{g} / \mathrm{L}$ in October to a maximum of $65.05 \mu \mathrm{g} / \mathrm{L}$ in December at open station and it varied from a low value of $12.13 \mu \mathrm{g} / \mathrm{L}$ in May to a high value of $48.77 \mu \mathrm{g} / \mathrm{L}$ in January at shore station. The annual mean biomass of the study lake was $31.21 \mu \mathrm{g} / \mathrm{L}$ and $26.3 \mu \mathrm{g} / \mathrm{L}$ at open and shore stations respectively. Significant seasonal variation of the biomass of phytoplankton was observed $(\mathrm{p}=0.029)$ in the study lake in that higher biomass was observed during dry season than rainy season. Biomass was correlated with some of the environmental variables. Pearson correlation coefficient analysis indicated that phytoplankton biomass correlated positively and strongly with $\mathrm{pH}(\mathrm{r}=0.543)$, conductivity $(\mathrm{r}=0.485)$, Secchi disk $(\mathrm{r}=0.467)$ and total alkalinity $(\mathrm{r}=0.576)$ whereas it correlated negatively and strongly with $\mathrm{NO}_{2}(\mathrm{r}=-0.550)$, TP $(r=-0.411)$ and TSS $(r=-0.658)$.

\section{Photosynthetic production}

In the estimation of photosynthetic production along the vertical profile using composite samples, the same amount of algal biomass was presumably exposed to the same levels of algal nutrients. Depth profiles of photosynthetic rates (GP) estimated as gram of carbon evolved per unit volume per given time $\left(\mathrm{g} \mathrm{C} \mathrm{m}^{-3} \mathrm{~h}^{-1}\right)$ in each sampling 
date are shown in Figure 3. The depth profiles included three main regions including near surface region of light-inhibition, a sub-surface region of light-saturation and a lower region of light-limitation.

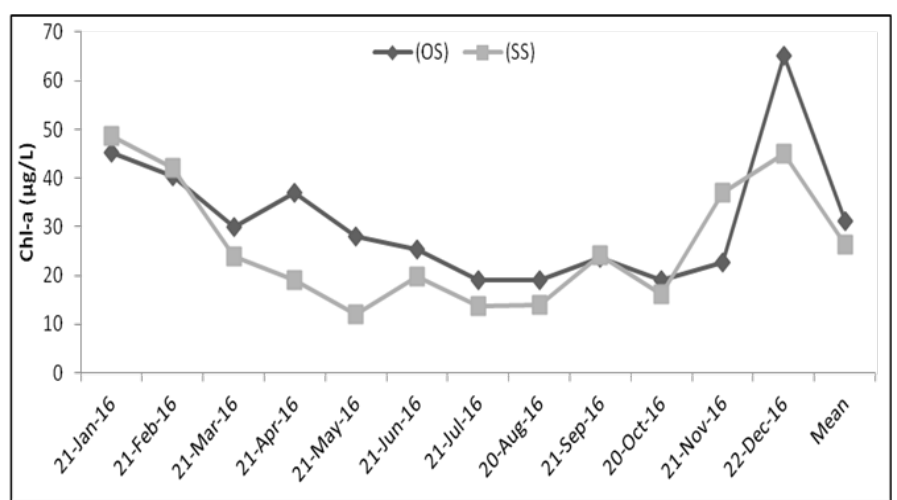

Figure 2 Temporal variations of phytoplankton biomass (chlorophyll- $a$ ) in Lake Tinishu Abaya at central/open station (OS) and near shore station (SS).

\section{Depth-Profiles of gross photosynthesis}

During the study period, the depth-profiles of gross photosynthesis exhibited a sub surface maximum rate of gross photosynthesis at 0.25 and $0.5 \mathrm{~m}$ in all sampling months. In six measuring months
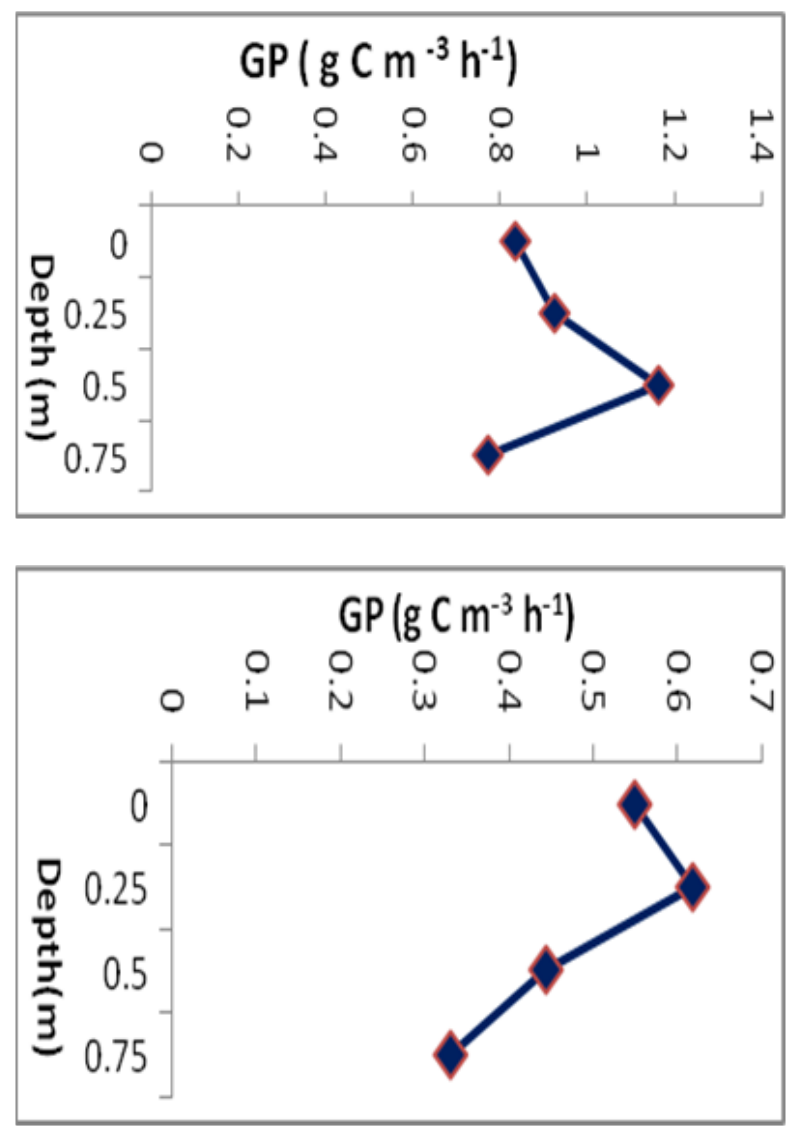

(March, April, May, June, November and December) maximum rate of gross photosynthesis were recorded at a sub-surface region of light-saturation at a depth of $0.25 \mathrm{~m}$ whereas in the remaining six months (January, February, July, August, September, and October) the maximum rate of gross photosynthesis were estimated at a subsurface region of light-saturation at a depth of $0.5 \mathrm{~m}$ (Figure 3). The maximum gross photosynthetic rate at light saturation was observed in July coinciding with a photosynthetic biomass of $19.09 \mathrm{Chl}-a \mathrm{mg} /$ $\mathrm{m}^{3}$ while the lowest gross photosynthetic rate was observed in March associated with a biomass of $29.9 \mathrm{Chl}-a \mathrm{mg} / \mathrm{m}^{3}$. Net photosynthetic rates showed a depth distribution pattern, which was similar pattern to that of gross photosynthesis with maximum volumetric rates at a depth of 0.25 and ranged from a minimum of absolute value of 285 $\mathrm{mg} \mathrm{O}_{2} \mathrm{~m}^{-3} \mathrm{~h}^{-1}\left(4.34 \mathrm{~g} \mathrm{C} \mathrm{m}^{-3} \mathrm{~h}^{-1}\right)$ in August to a maximum of $1285 \mathrm{mg}$ $\mathrm{O}_{2} \mathrm{~m}^{-3} \mathrm{~h}^{-1}\left(7.28 \mathrm{~g} \mathrm{C} \mathrm{m}^{-3} \mathrm{~h}^{-1}\right)$ in December.

Considering the significance of inhibition of photosynthesis at a lake's surface for water column productivity, the extent of percentage reduction in gross photosynthesis from maximum light-saturated rate of photosynthesis $\left(\mathrm{A}_{\max }\right)$ due to photo-inhibition was estimated by calculating the difference between maximum gross photosynthetic rate and gross photosynthetic rate at the surface and expressing it as a percentage of the latter. The reduction in photosynthetic rates due to photo-inhibition varied from $12.5 \%$ in March to $62.07 \%$ in November.
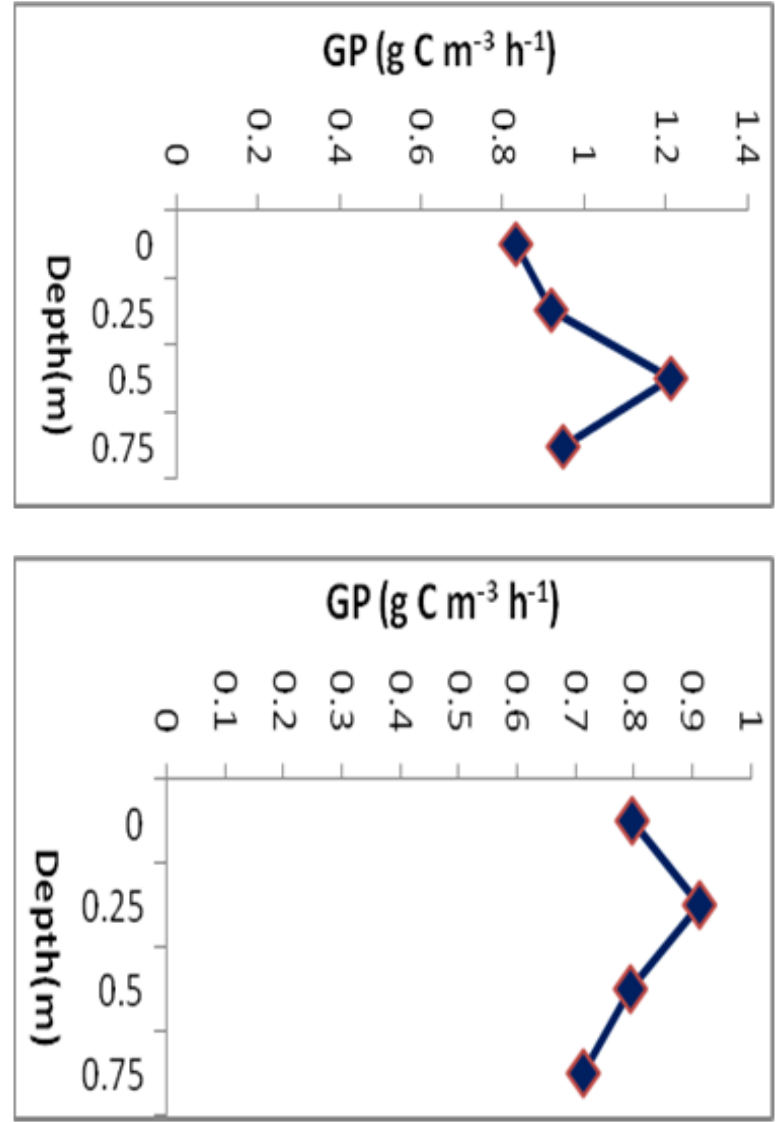

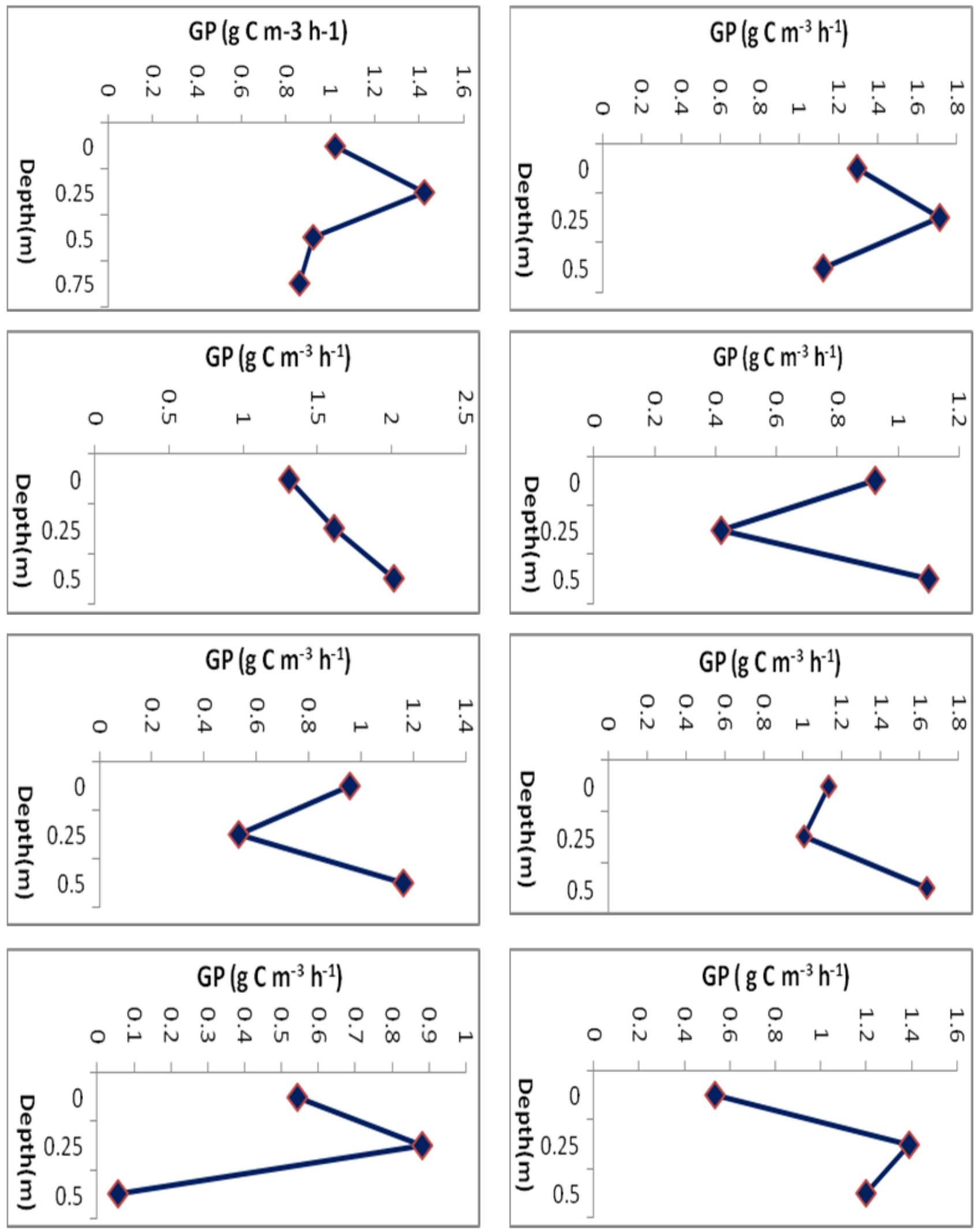

Figure 3 Depth profiles of gross photosynthesis per unit volume (GP, $\left.\mathrm{g} \mathrm{C} \mathrm{m}^{-3} \mathrm{~h}^{-1}\right)$ at open station during the study period (January to December, 2016). 


\section{Photosynthetic characteristics}

In the study lake in addition to depth profile photosynthetic productivity, different characteristics related to phytoplankton productivity were assessed. These photosynthetic characteristics considered in the study area were includes phytoplankton biomass (Chl- $a$ per unit water volume (B, mg Chl- $\left.a \mathrm{~m}^{-3}\right)$, maximum lightsaturated rate of photosynthesis $\left(\mathrm{A}_{\max }, \mathrm{mg} \mathrm{O}_{2} \mathrm{~m}^{-3} \mathrm{~h}^{-1}\right)\left(\mathrm{g} \mathrm{C} \mathrm{m}^{-3} \mathrm{~h}^{-1}\right)$, Specific rate of photosynthesis at maximum light saturation $\left(\mathrm{P}_{\text {max }} \mathrm{mg}\right.$ $\left.\mathrm{O}_{2}(\mathrm{mg} \mathrm{Chl}-\mathrm{a})^{-1} \mathrm{~h}^{-1}\right)\left(\mathrm{g} \mathrm{C}(\mathrm{mg} \mathrm{Chl} \mathrm{a})^{-1} \mathrm{~h}^{-1}\right)$, Hourly integral rates of photosynthesis $\left(\Sigma \mathrm{A}, \mathrm{mg} \mathrm{O}_{2} \mathrm{~m}^{-2} \mathrm{~h}^{-1}\right)\left(\mathrm{g} \mathrm{C} \mathrm{m}^{-2} \mathrm{~h}^{-1}\right)$, Daily integral rates of photosynthesis $\left(\Sigma \Sigma \mathrm{A}, \mathrm{mg} \mathrm{O}_{2} \mathrm{~m}^{-2} \mathrm{~d}^{-1}\right)\left(\mathrm{g} \mathrm{C} \mathrm{m}^{-2} \mathrm{~d}^{-1}\right)$, and Percentage reduction (\% Reduction) of gross photosynthesis and all are put in Table 2 below. The maximum rates of phytoplankton photosynthesis $\left(\mathrm{A}_{\max }\right)$ varied from the lowest value of $495 \mathrm{mg} \mathrm{O}_{2} \mathrm{~m}^{-3} \mathrm{~h}^{-1}(0.62 \mathrm{~g} \mathrm{C}$ $\left.\mathrm{m}^{-3} \mathrm{~h}^{-1}\right)$ in March to the highest value of $1613.5 \mathrm{mg} \mathrm{O}_{2} \mathrm{~m}^{-3} \mathrm{~h}^{-1}(2.02 \mathrm{~g} \mathrm{C}$ $\mathrm{m}^{-3} \mathrm{~h}^{-1}$ ) in July. Its mean value was estimated to be $931.65 \mathrm{mg} \mathrm{O}_{2} \mathrm{~m}^{-3} \mathrm{~h}$ ${ }^{1}\left(1.269 \mathrm{~g} \mathrm{C} \mathrm{Cm}^{-3} \mathrm{~h}^{-1}\right)$. Biomass-specific rate of gross photosynthesis at light saturation $\left.\left(\mathrm{P}_{\max }, \mathrm{A}_{\max } / \mathrm{B}, \mathrm{mg} \mathrm{O}_{2}(\mathrm{mg} \mathrm{chl}-a)^{-1}\right) \mathrm{h}^{-1}\right)(\mathrm{g} \mathrm{C}(\mathrm{mg}$ $\mathrm{Chl} a)^{-1} \mathrm{~h}^{-1}$ ) has been used to estimate the photosynthetic capacity (assimilation number) of phytoplankton (Morris, 1980). In this study it ranged from a minimum of $\left.16.56 \mathrm{mg} \mathrm{O}_{2}(\mathrm{mg} \mathrm{Chl}-a)^{-1}\right) \mathrm{h}^{-1}(0.02 \mathrm{~g} \mathrm{C}$ $\left.(\mathrm{mg} \mathrm{Chl} a)^{-1} \mathrm{~h}^{-1}\right)$ to a maximum value of $\left.84.52 \mathrm{mg} \mathrm{O}_{2}\left(\mathrm{mg} \mathrm{Chl}^{-a}\right)^{-1}\right)$ $\mathrm{h}^{-1}\left(\left(0.106 \mathrm{gC}(\mathrm{mg} \mathrm{Chl}-a)^{-1} \mathrm{~h}^{-1}\right)\right.$ with the annual mean value of 38.57 $\left.\mathrm{mg} \mathrm{O}_{2}(\mathrm{mg} \mathrm{Chl} a)^{-1}\right) \mathrm{h}^{-1}\left(0.048 \mathrm{gC}(\mathrm{mg} \mathrm{Chl} a)^{1} \mathrm{~h}^{-1}\right)$. In the study lake the hourly rate of gross photosynthesis per unit area $\left(\sum \mathrm{A}\right)$, varied from low value of $46.54 \mathrm{mg} \mathrm{O}_{2} \mathrm{~m}^{-2} \mathrm{~h}^{-1}\left(0.60 \mathrm{~g} \mathrm{C} \mathrm{m}^{-} \mathrm{h}^{-1}\right)$ in April to high value of $659.17 \mathrm{mg} \mathrm{O}_{2} \mathrm{~m}^{-2} \mathrm{~h}^{-1}\left(1.022 \mathrm{gC} \mathrm{m}^{-2} \mathrm{~h}^{-1}\right)$ in July with a mean value of $394.77 \mathrm{mg} \mathrm{O}_{2} \mathrm{~m}^{-2} \mathrm{~h}^{-1}\left(0.642 \mathrm{~g} \mathrm{C} \mathrm{m}^{-2} \mathrm{~h}^{-1}\right)$, whereas the calculated pattern of variation for the daily integral rates of photosynthesis $(\Sigma \Sigma \mathrm{A})$ values was ranged from a minimum of $482.91 \mathrm{mg} \mathrm{O}_{2} \mathrm{~m}^{-2} \mathrm{~d}^{-1}\left(5.43 \mathrm{~g} \mathrm{C} \mathrm{m}^{-2} \mathrm{~d}^{-1}\right)$ to a maximum of $5932.5 \mathrm{mg} \mathrm{O}_{2} \mathrm{~m}^{-2} \mathrm{~d}^{-1}\left(9.19 \mathrm{~g} \mathrm{C} \mathrm{m}^{-2} \mathrm{~d}^{-1}\right)$ with mean value of $3358.27 \mathrm{mg} \mathrm{O}_{2} \mathrm{~m}^{-2} \mathrm{~d}^{-1}\left(5.78 \mathrm{~g} \mathrm{C} \mathrm{m}^{-2} \mathrm{~d}^{-1}\right)$, with a similar pattern with aerial gross photosynthesis.

The productivity of each parameter had a correlation with physicochemical factors which cause the seasonality of phytoplankton productivity. The correlation between the different photosynthetic characteristics and the physicochemical parameters observed in the present study were found in table 3. The maximum rates of phytoplankton photosynthesis $\left(\mathrm{A}_{\max }\right)$ correlated strongly and negatively with $\mathrm{pH}$. Even not strong it also correlated negatively with total alkalinity, conductivity, SRP, DO and Secchi disk. On the other hand, $\mathrm{A}_{\max }$ correlated positively but weakly with TSS, Turbidity, $\mathrm{NH}_{4}$ and TP. The maximum rates of phytoplankton photosynthesis also correlated with other photosynthetic characteristics. It correlated positively and significantly with $\mathrm{P}_{\max }, \sum \mathrm{A}$, and $\sum \sum \mathrm{A}$. $\mathrm{P}_{\max }$ correlated strongly and positively with TSS, turbidity, Amax and $\sum \sum A$.

Table 2 Phytoplankton biomass ( $\mathrm{Chl}-a$ per unit water volume $\left(\mathrm{B}, \mathrm{mg} \mathrm{Chl}-a \mathrm{~m}^{-3}\right)$, maximum light- saturated rate of photosynthesis $\left(\mathrm{A}_{\max }, \mathrm{mg} \mathrm{O}_{2} \mathrm{~m}^{-3} \mathrm{~h}^{-1}\right)(\mathrm{g} \mathrm{C}$ $\left.\mathrm{m}^{-3} \mathrm{~h}^{-1}\right)$, Specific rate of photosynthesis at maximum light saturation $\left(\mathrm{P}_{\text {max }} \mathrm{mg} \mathrm{O}_{2}(\mathrm{mg} \mathrm{Chl}-\mathrm{a})^{-1} \mathrm{~h}^{-1}\right)\left(\mathrm{g} \mathrm{C}(\mathrm{mg} \mathrm{Chl}-\mathrm{a})^{-1} \mathrm{~h}^{-1}\right)$, Hourly integral rates of photosynthesis $\left(\Sigma \mathrm{A}, \mathrm{mg} \mathrm{O}_{2} \mathrm{~m}^{-2} \mathrm{~h}^{-1}\right)\left(\mathrm{g} \mathrm{C} \mathrm{m}^{-2} \mathrm{~h}^{-1}\right)$, Daily integral rates of photosynthesis $\left(\Sigma \Sigma \mathrm{A}, \mathrm{mgO}_{2} \mathrm{~m}^{-2} \mathrm{~d}^{-1}\right)\left(\mathrm{g} \mathrm{C} \mathrm{m}^{-2} \mathrm{~d}^{-1}\right)$, and Percentage reduction (\% Reduction) of gross photosynthesis for Lake Tinishu Abaya (January- December, 2016).

\begin{tabular}{|c|c|c|c|c|c|c|}
\hline \multirow{2}{*}{ Date } & \multicolumn{6}{|c|}{ Parameters } \\
\hline & B & $\mathbf{A}_{\max }$ & $\mathbf{P}_{\max }$ & $\sum \mathbf{A}$ & $\Sigma \Sigma \mathbf{A}$ & \% Redu \\
\hline January & 45.33 & $930(1.16)$ & $20.5(0.026)$ & $555(0.69)$ & 4995 (6.23) & 38.81 \\
\hline February & 40.52 & $970(1.21)$ & $23.94(0.03)$ & $586.88(0.74)$ & $5281.88(6.6)$ & 45.86 \\
\hline March & 29.9 & $495(0.62)$ & $16.56(0.02)$ & $291.56(0.36)$ & $2624.06(3.28)$ & 12.5 \\
\hline April & 37.01 & $730(0.91)$ & $19.72(0.025)$ & $46.54(0.60)$ & 482.91 (5.43) & 14.3 \\
\hline May & 28.01 & 1140 (I.43) & $40.7(0.05)$ & $635.9(0.795)$ & $5723.16(7.15)$ & 39.02 \\
\hline June & 25.34 & I37| (I.7I) & $54.1(0.068)$ & $551.25(0.964)$ & 4961.25 (8.678) & 32.27 \\
\hline July & 19.09 & I613.5 (2.02) & $84.52(0.106)$ & 659.17 (1.022) & $5932.5(9.194)$ & 23 \\
\hline August & 19.12 & $880(I . I)$ & $46.02(0.057)$ & $325.83(0.58)$ & $2932.5(5.22)$ & 18.92 \\
\hline September & 23.56 & $930(1.16)$ & $39.47(0.049)$ & $353.33(0.56)$ & $3180(5.04)$ & 21.57 \\
\hline October & 18.97 & $1310.48(1.64)$ & $69.08(0.086)$ & $504.03(0.63)$ & $4536.29(5.67)$ & 44.44 \\
\hline November & 22.67 & $705(0.88 I)$ & 31.1 (0.039) & $197.5(0.247)$ & I 777.5 (2.22) & 62.07 \\
\hline December & 65.05 & III I2.9 (I.39) & $|7.1|(0.02 \mid)$ & $416.66(0.521)$ & $3750(4.688)$ & 61.59 \\
\hline Mean & 31.21 & 931.65 (1.269) & $38.57(0.048)$ & $394.77(0.642)$ & $3558.27(5.78)$ & 34.53 \\
\hline
\end{tabular}

\section{Discussion}

\section{Physicochemical features}

\section{Surface temperature and dissolved oxygen}

In the study area, a considerable temperature fluctuation was observed and this temperature fluctuation could be influenced considerably by meteorological factors such as air temperature, humidity, wind speed, solar radiation and climatic factors. Low temperature reported during some rainy season (August and September) may be due to cold low ambient temperature and shorter photoperiod. On the other hand high temperature reported in some rainy seasons (June and July) is possibly due to the presence of cloudy weather. Generally, higher temperature recorded in dry season than wet season and this owing to high solar radiation, low water level and clear atmosphere. The concentration of oxygen was relatively high which indicated the lake is well oxygenated. Dissolved oxygen showed temporal variation and this fluctuation could be the result 
of the variations observed in phytoplankton photosynthetic activity, thermal regime and/or changes in the weather conditions of the lake area. Higher concentration of DO recorded in dry season probably associated with increased areal biomass and prominent stratification from January to March as can be seen from depth profiles of temperature and DO. High algal biomass produces more dissolved oxygen in aquatic systems ${ }^{21}$ during the light hours of the day. The low level of DO observed in the rainy season might be associated with relatively low phytoplankton biomass, more cloud cover and the inflow of decomposing organic matter with runoff into the lake. ${ }^{4}$

Despite that Duchane observed that wind is a major oxygenator and that dissolved oxygen in smaller lakes is also determined by photosynthetic action of phytoplankton. In agreement to that observation complete oxygen depletion was not observed in any of the stations in the lake, apparently because of significant water movement through the lake as a result of mass water movement due to frequent top-down mixing by wind action. A similar fact was observed in Lake Tinishu Abay where oxygen was not completely depleted throughout the study period owing to its water movement and presence of photosynthetic activity.

\section{Depth profile of temperature and dissolved oxygen}

In the study of depth profile of temperature, the decline in temperature per meter of depth by about $1^{\circ} \mathrm{C}$ or more than $1^{\circ} \mathrm{C}$ with increasing depth was observed near the surface in the $0-2 \mathrm{~m}$ depth layer in three months of the sampling period (January, February and March) and in all the remaining sampling months (April-December) temperature differences was less than $1^{\circ} \mathrm{C}$ down the column. In the $0-1 \mathrm{~m}$ depth layer, temperature gradients varied from $2.3^{\circ} \mathrm{C}$ in March to $3^{\circ} \mathrm{C}$ in January and in the $1-2 \mathrm{~m}$ depth layer, temperature gradients varied from $2.6^{\circ} \mathrm{C}$ in February to $2.9^{\circ} \mathrm{C}$ in January and there is no temperature stratification observed below $2 \mathrm{~m}$ in all sampling months. From depth profiles of temperature investigations, as expected from shallow and small lake, persistent thermal stratification was not observed throughout the study period. The absence of this wellmarked and persistent deep-seated thermal stratification owing to exposure to wind action which induces the persistence of complete mixing and difficult to see thermocline on depth profile in this very shallow lake. Thermal stratification with thermoclines extending between 2 and $7 \mathrm{~m}$ in Lake Hora Kilole was observed in 1990-1991 22 which was associated with the increased depth attained after diversion of River Mojo and the cone-shaped water basin, which prevented wind, induced mixing. In Lake Tinishu Abaya similar thermal stratification was not observed even if the lake depth was increased during rainy season as a result of an increment of water availability via Rivers Bobodo and Dacha.

From the study of depth profiles of dissolved oxygen of Lake Tinishu Abaya, all depth profiles showed oxygen maximum in the upper layer of the water column and it declined with increasing depth, which possibly due to the greater demand for oxygen for oxidative decomposition of organic matter by heterotrophs. Oxygen-maxima were observed between $0-0.5 \mathrm{~m}$ depths in most of the sampling months. Oxygen-maximum was found at a shallow depth near the surface (at $0.5 \mathrm{~m}$ depth) in January, February and April. In these sampling months, the observed oxygen-maximum was may be associated with a superficial thermal stratification, which usually implies a steep temperature gradient in the uppermost $0-2 \mathrm{~m}$ stratum during warm and calm weather, and this gradient is a barrier to turbulent mixing resulting in in-situ accumulation of oxygen produced by photosynthesis. Depth maximum of oxygen can be formed when thermal gradient in the water column occurs within the photosynthetic zone. ${ }^{22}$ From the study of oxygen depth profiles of Ethiopian creator lake, L Bishoftu and Kuriftu ${ }^{4}$ lakes, and the Ethiopian rift valley lakes Chamo, Hawassa and Ziway ${ }^{5}$ and other Ethiopian lakes, Baxter et al., ${ }^{22}$ indicated that most of the lakes showed an oxygen maximum in the uppermost $0-5 \mathrm{~m}$ layer, and in Lake Tinishu Abaya a similar feature was observed. The decline in oxygen concentration near the water surface in some tropical lakes is accentuated by the influence of rising temperature on the saturation concentration ${ }^{23}$ and photo-inhibition. ${ }^{23,25}$ Beadle ${ }^{26}$ argued that the major determinant of circulation in tropical lakes is wind rather than the seasonal fluctuations of illumination and atmospheric temperature. Pearson correlation analysis of the resent study indicated that temperature and DO correlated strongly and negatively $(\mathrm{r}=-0.449)$. On rainy season (August) of sampling day where increasing water level of the study lake, the value of DO were low in the part of the water column, a situation was observed in Lake Hora Kilole after attaining higher depth due to diversion of River Mojo into it. ${ }^{22}$

\section{$\mathrm{pH}$ and alkalinity}

In the present investigation, the $\mathrm{pH}$ value showed that the water of Lake Tinishu Abaya was alkaline in nature throughout the study period. High value of $\mathrm{pH}$ was observed during dry period and this might be low water levels and concentration of nutrients in water and may be attributed to high photosynthetic activity. The decrease $\mathrm{pH}$ values during the period of main rainy season owing to dilution caused by the rainwater and may be the results of the production of $\mathrm{CO}_{2}$ from biological oxidation process and may have ultimately contributed to the reduction of $\mathrm{pH}$. The alkalinity values were maximum during dry season and this highest value of alkalinity reported during dry period may be due to the accumulation of organic matters produced by decay and decomposition of vegetation and in turn, added carbonate and bicarbonate concentrations in the lake water content and this may be attributed to increase the rate of organic decomposition during which $\mathrm{CO}_{2}$ is liberated, which reacts with water to form $\mathrm{HCO}$, thereby increasing the total alkalinity. The lowest alkalinity concentration was recorded during rainy season could be related to the inflow of water and dissolution of calcium carbonate ions in the water column caused by the rainwater. $\mathrm{BSI}^{27}$ recommendation of $\mathrm{pH}$ is $6.5-8.5$ for optimal survival of most aquatic life. A lower value of $\mathrm{pH}$ below 4 will produce sour taste. The minimum values of $\mathrm{pH}$ of the study lake is within the maximum permissible limits of ${ }^{28}$ for recreation, agricultural, fish production and other aquatic life water use (6.5-8.5/9) however it was alkaline throughout the year. The alkalinity results suggest that the lake has high productivity.

\section{Turbidity,TSS,TDS and water transparency}

As recorded in this study, Lake Tinisu Abaya was very turbid throughout the study period with a peak during the main rainy seasons (June to September). The maximum turbidity recorded in July was about 2.5 times greater than the minimum value measured in January. This higher turbidity in the rainy season might be the result of high rainfall which brought sediment-laden waters from the surface runoff and rivers (Bobodo and Dacha) and because of surface run-off water with soil, domestic waste, cattle washing, bathing activity etc. The low turbidity values in dry season may be due to clear atmosphere, evaporation of water and high light penetration.

High TSS was found during rainy season; this might be due to the effect of high run off of solid particles from the watershed/ agriculturally rich catchment area of the lake and may be due to 
siltation, deterioration, heavy precipitation and mixing run off rain water which carried mud, sand etc mixed in the lake water. Likewise the lake had relatively high TDS trough out the study and its high value was observed during the rainy season and the increase in TDS might be due to increased amount of discharges, erosion and organic detritus load. According to FAO recommendations, the acceptable range for live stock drinking is $(100-1,500 \mathrm{mg} / 1)$. Water with total ionic concentration $<3000 \mathrm{mg} / \mathrm{L}$ ) is considered fresh. Lake Tinishu Abaya is fresh based on the results of TDS measurements throughout the year and recommendable for live stock drinking including fish production.

Lake Tinishu Abaya had relatively low water transparency throughout the study period in both sampling sites and, therefore, the lake is generally regarded as a productive lake. The significant lower water transparency at shore station is most likely due to wind induced re-suspension of bottom sediments and this operate the large turbulence and sediment instability which in turn reduces the depth of light penetration. During the period of sampling, a lot of human activities including swimming, washing clothes, watering animals and damping of wastes were observed on the shore station and these activities may persuade and cause re-suspension of particles, have probably contributed to the difference in water clarity between the two stations. Particularly at shore site low values of transparency was revealed could be due to exclusive addition of sewage results increased turbidity, adversely affecting the transparency. High and low values of water transparency coincided with dry and rainy seasons respectively. The temporal variations observed in the transparency of Lake Tinishu Abaya seem to be related to changes in the levels of re-suspension of inorganic articles resulting from wind-driven mixing, variation in phytoplankton biomass and external loading of particulate materials from the watershed through runoff. Low water transparency during the rainy season may be because of high flushing rate, inorganic silt turbidity, and high loading of dissolved inorganic matter from the inflowing rivers, which is likely any other tropical lake. ${ }^{29}$

\section{Biomass of phytoplankton}

In the study lake the lowest phytoplankton biomass was observed during rainy season (June to September (Figure 2). This seasonal minimum Chl $a$ in rainy seasons coincided with a period of heavy precipitation that resulted in land runoff which brought particulate materials into the lake with consequent reduction in light penetration. The occurrence of low phytoplankton biomass in lakes during periods of heavy rainfall was also reported for Lakes Victoria. The peak in phytoplankton biomass, which was observed in December (Dry period) for the open station, may be coincided with an increase in $\mathrm{NO}_{3}-\mathrm{N}$ and TP-P levels while that of the shore station occurred in January concomitant with high water transparency which provoke light penetration. The decline of phytoplankton biomass in dry season (January, April and May) was probably associated with the peak abundance of rotifers and fairly low level of most of the inorganic nutrients. Rotifers particularly Brachionu ssp. can have a considerable effect on phytoplankton as they are known to resist the toxicity of blue greens although they mainly ingest particulate material. Temporal dynamics of phytoplankton biomass are known to be controlled by loss processes including grazing by zooplankton and fish..$^{30}$

\section{Primary production}

Depth profiles of photosynthetic features

The depth profiles of photosynthetic activity observed for
Lake Tinishu Abaya exhibited depressed rates of photosynthesis at the near surface of the water columns during all of the sampling months. Profiles with reduced surface photosynthetic activity or rate during measurement of primary productivity in water bodies have been documented for many African lakes including those in Ethiopia $^{5,20,31,32}$ in Kenya ${ }^{33,34}$ and in Tanzania. ${ }^{35,36}$ Basically, lower photosynthetic rates of phytoplankton at a lake's surface are linked to photo inhibition, which is believed to occur when light exceeds physiological saturation and results in excess of photons that do not become dissipated by photosynthetic carbon fixation. ${ }^{37}$ The extent of surface depression of photosynthetic rates is not a function of only the intensity of incident irradiance. Experimental studies have shown that the extent of photo-inhibition varies with photo-acclimatization state $^{38}$ and species-specific differences in photo-acclimatization strategies. The decrease in photosynthetic rates is associated with photo-oxidative disruption of pigment systems, ${ }^{37}$ inactivation of photosynthetic enzymes and increased photorespiration. Exposure to inhibiting irradiance for prolonged periods has been shown to increase the effect of photo-inhibition. In the present study there was not measured the photosynthetic active radiation (PAR), however, the turbidity of the lake was high and the water transparency (Secchi disc) generally very low, and it can conclude there was high possibility for photo inhibition in the study lake that cause the lower photosynthetic rates of phytoplankton at a lake's surface. The correlation between maximum gross photosynthesis and water turbidity in the present study was negative yet not strong (Table 3 ).

Table 3 Relationship between photosynthetic characteristics and physicochemical parameters

\begin{tabular}{llllll}
\hline Parameters & Amax & Pmax & $\Sigma$ A & $\Sigma \Sigma$ A & Biomass \\
\hline Total alkalinity & -0.453 & $-.673^{*}$ & -0.171 & -0.167 & 0.537 \\
TSS & 0.457 & $.619^{*}$ & 0.291 & 0.293 & -0.551 \\
TDS & 0.231 & 0.507 & 0.115 & 0.115 & $-.625^{*}$ \\
Turbidity & -0.563 & $.638^{*}$ & 0.088 & 0.086 & -0.334 \\
Secchi disk & -0.558 & $-.752^{* *}$ & -0.074 & -0.071 & 0.514 \\
$\mathrm{CO}_{2}$ & -0.432 & $-.657^{*}$ & -0.104 & -0.102 & $.587^{*}$ \\
$\mathrm{PH}$ & $-.600^{*}$ & $-.709^{* *}$ & -0.198 & -0.197 & 0.55 \\
$\mathrm{~A}_{\max }$ & $\mathrm{I}$ & $.804^{* *}$ & $.742^{* *}$ & $.744^{* *}$ & -0.162 \\
$\mathrm{P}_{\max }$ & $.804^{* *}$ & $\mathrm{I}$ & 0.485 & 0.486 & $-.683^{*}$ \\
$\Sigma \mathrm{A}$ & $.742^{* *}$ & 0.485 & $\mathrm{I}$ & $1.000^{* *}$ & -0.017 \\
$\Sigma \sum \mathrm{A}$ & $.744^{* *}$ & 0.486 & $1.000^{* *}$ & $\mathrm{I}$ & -0.016 \\
$\%$ Saturation & 0.095 & 0.115 & 0.255 & 0.253 & -0.199 \\
\hline
\end{tabular}

*.Correlation is significant at the 0.05 level $(2-$ tailed). $* *$. Correlation is significant at the 0.01 level (2- tailed)

The depth profiles of photosynthesis had steep curves in most months at the shallow depths. Similar depth profiles of photosynthesis with similar pattern of photosynthetic curves were observed for productive tropical lakes of Ethiopia such as L. Kilole, Ziway, Awassa, Chamo, Kuriftu and Bishoftu. In Lake George and many soda lakes of East Africa with abundant phytoplankton, ${ }^{35}$ the euphotic zone is less than $1 \mathrm{~m}$ deep and photosynthetic depth profiles are correspondingly condensed. Such kind of dense phytoplankton assemblage with a condensed photosynthetic zone can have implications for intense $\mathrm{CO}_{2}-$ demand by photosynthesis per unit water volume, and such demand leads to considerable $\mathrm{CO}_{2}$-depletion. ${ }^{38}$ In the present study $\mathrm{CO}_{2}$ 
correlated negatively with $\mathrm{A}_{\max }$ which showed a depletion of $\mathrm{CO}_{2}$ by photosynthesis. Estimation of percentage reduction of photosynthesis at the surface from the volumetric rate of gross photosynthesis at light-saturation $\left(\mathrm{A}_{\max }\right)$ below water surface showed low value, $12.5 \%$ in March, may be coincident with cloud cover. Similarly, Melack ${ }^{23}$ and Tadesse Ogato ${ }^{32}$ in Lake Bishoftu, Zelalem Desalegn ${ }^{4}$ in Lake Kuriftu and Girma Tilahun ${ }^{5}$ in Lake Hawassa and Ziway, observed depth profiles of photosynthesis lacking a region with reduced rates near the surface during a cloudy day. High percent reductions was seen in November (62.07\%), December (61.59\%), February (45.58\%) and October (44.44\%) which corresponded with high water clarity.

On all occasions, below the depths of $\mathrm{A}_{\max }$, volumetric rates of gross photosynthesis declined progressively. In rainy months the curve terminated at shallower depths following low water clarity which affected light penetration. In general, the observed photosynthetic rates were high; a feature of tropical lakes.. ${ }^{24}$ From the comparative studies of photosynthetic rates of temperate and tropical lakes Lemoalle concluded that the generally higher tropical rates stem mainly from higher values of photosynthetic capacity associated with higher temperature. Others suggested that nutrient regeneration is more rapid and primary production is high in tropical than in temperate lakes ${ }^{26,40}$ due to high temperatures at all depths. In Lake Thishu Abaya relatively high temperature was observed in all depth profiles and only less than $2^{\circ} \mathrm{C}$ difference between the lower and the upper depth in most of the sampling dates, yet to be paid the relatively high photosynthetic rates observed. The correlation between temperature and all of the photosynthetic parameters are positive but weak in the present study.

\section{Photosynthetic characteristics}

The present maximum rates of photosynthesis $\left(\mathrm{A}_{\mathrm{max}}\right)$ of Lake Tinishu Abaya is broadly comparable to those reported for other Ethiopian Lakes; e.g. L. Chamo, Abijata and Bishoftu but higher than those reported for Lake Awassa. However, it is much lower than values reported for other Ethiopian lakes as Lakes Kilole and Arenguade. Specific rate of photosynthesis at maximum light saturation $\left(\mathrm{P}_{\max }\right)$ for Lake Tinishu Abaya was found to be higher than the Ethiopian Rift Vale Lakes Ziway, Awassa, Chamo and creator Lakes Arenguade and Kilole. $\mathrm{P}_{\max }$ for Lake Tinishu Abaya is nearly closer to values reported for productive creator Lake Bishoftu. The hourly integral photosynthesis rate in Lake Tinishu Abaya was comparable with Lakes Ziway but lower than Lake Bishoftu. The maximum daily integral rates of photosynthesis in this study lake was nearly closer with the rift valley Lakes Awassa and Chamo. Weak and insignificant positive correlations between $\mathrm{A}_{\max }$ and $\mathrm{Chl}-a$ were observed for Lakes Ziway $\left(r=0.09^{5}\right)$ and Chamo $\left(r=0.09\right.$, Eyasu Shumbulo $\left.{ }^{39}\right)$ in Ethiopia. However, strong and positive correlations between $\mathrm{A}_{\max }$ and Chl- $a$ have been observed for lakes in Kenya ${ }^{23}$ and Wales ${ }^{41}$ and Sri Lankan reservoirs. ${ }^{42}$ In the present study weak but negative correlation ( $\mathrm{r}=$ -0.162) was observed between $A_{\text {max }}$ and chlorophyll-a. Smith ${ }^{43}$ has shown the presence of strong and positive correlation between $\mathrm{A}_{\max }$ and inorganic nutrients $(\mathrm{N}$ and $\mathrm{P})$.

In this study, the relation with Nitrogen and phosphorous nutrients was positive but not strong. Temporal variations in $A_{\max }$ seem to be influenced more by the concentration of nutrients than algal biomass. The relationship between algal nutrients and $\mathrm{A}_{\max }$ was very poor. In Lake Tinishu Abaya maximum light-saturated rate of photosynthesis correlated positively with some of the nutrients such as $\mathrm{NO}_{2}, \mathrm{NH}_{4}$ and TP whereas it was correlated negatively with biomass (Table 3 ). From

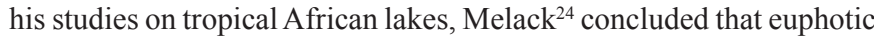
depth was inversely correlated with maximum photosynthetic rates, a similar circumstance was observed in the present study lake. The observed maximum values of specific rate of photosynthesis at maximum light saturation are unusually high compared to those of other Ethiopian lakes. Various authors have suggested explanations for the unusually high values of photosynthetic capacity obtained from tropical waters. These variations in $\mathrm{P}_{\text {max }}$ may be the lake size, shallowness and hence mixing capacity of the water, availability in concentration of algal and inorganic nutrients. The specific rate of photosynthesis at maximum light saturation $\mathrm{P}_{\max }$ highly was influenced by algal biomass and concentration of nutrients.

In the study area, the specific rate of photosynthesis at maximum light saturation correlated negatively and strongly with phytoplankton biomass $(\mathrm{r}=-0.683)$. Examples of inverse correlation between $\mathrm{P}_{\max }$ and algal biomass were documented for tropical lakes including Lake George ${ }^{44}$ and Lake Ebrie. Inverse correlation with biomass was also reported by Harrison and Platt (1980) in their study of environmental control of assimilation number and in Kinnego Bay, by Jones. Nutrient availability, particularly nitrite and total phosphorus and turbidity of water seem to control photosynthetic capacity in this study lake. This is consistent with the argument that nutrient availability is more important in controlling photosynthetic capacity of phytoplankton populations (Falkowuski and Stone, 1983). The higher $\mathrm{P}_{\max }$ (assimilation number) of phytoplankton ${ }^{45}$ in Lake Tinishu Abaya was reported in July and this high $\mathrm{P}_{\max }$ might be associated with low algal biomass. Melack et al. ${ }^{7}$ suggested that in lakes not enriched by human activities, gross photosynthetic rates of $30 \mathrm{~g} \mathrm{O}_{2}$ $\mathrm{m}^{-2} \mathrm{~d}^{-1}\left(c a .11 \mathrm{~g} \mathrm{C} \mathrm{m}^{-2} \mathrm{~d}^{-1}\right)$ or greater are seldom encountered. More recently, Melack ${ }^{24,46}$ reported similar values for the phytoplankton of Lake Simbi (Kenya). The mean primary productivity of streams and lake of the world is about $0.6 \mathrm{~g} \mathrm{C} \mathrm{m}^{-2} \mathrm{~d}^{-1}$ ), making these the most productive aquatic environments anywhere in the world. ${ }^{35,45}$ It is generally considered that photosynthetic primary productivity, mainly the result of the dense bloom of cyanobacteria, supports the rest of the microbial community. In this study lake, the daily photosynthetic productivity is high $\left(5.78 \mathrm{~g} \mathrm{C} \mathrm{m}^{-2} \mathrm{~d}^{-1}\right)$ compared to the water bodies stated by Melack et al. ${ }^{35}$ \& Oduor et al. ${ }^{45}$ Thus Lake Tinishu Abaya is most probably considered as high productive lake in relation to the primary productivity of phytoplankton and a basis for fish production.

\section{Conclusion}

The results of most of the physicochemical parameters and major inorganic nutrient analysis indicated that the productivity of the lake water is suitable for the survival of most freshwater aquatic organisms. The lake water is well oxygenated, slightly warm, alkaline, contained more TSS, and EC, very turbid and low transparency. The lake water is found to be fresh water with low salinity as indicated by the results of ionic contents or TDS. At the same time, the essential inorganic nutrients were relatively high to support freshwater aquatic organisms. In the present study, photosynthetic productivity for phytoplankton in Lake Tinishu Abay was mainly investigated and the results revealed that the presence of relatively high phytoplankton production and biomass could be support the growth of fish in the lake if the fishery practice is sustainably managed. ${ }^{46-51}$

\section{Acknowledgements}

The authors would like to thank the Ministry of Education of Ethiopia for funding this study and the Department of Zoological 
Sciences of Addis Ababa University for assisting us in laboratory facilities. Bureau of Cultural and Tourism for Selttie Woreda (Ethiopia) is also acknowledged for allowing us to access the study area.

\section{Conflict of interest}

The author declares there is no conflict of interest.

\section{References}

1. Sarvesh K, Sharma BK, Sharma SK, et al. Primary productivity and phytoplankton diversity in relation to fisheries potential of the Lake UdaiSagar, Udaipur. IJFBS. 2015;2(5):09-12.

2. Ahlgren G, Van- Nieuwerburgh L, Wanstrand I. Imbalance of fatty acids in the base of the Baltic Sea food web - a mesocosm study. Can J Fish Aquat Sci. 2005;62:2240-2253.

3. Hooker E, Chow- Wong N, Rivas K. Primary production and estimation of potential fish yield in Lake Cocibloca, Nicaragua. Verh Int Ver Limnol. 2001;27:3589-3594.

4. Zelalem D. Photosynthetic productivity and biomass of phytoplankton, in Lake Kuriftu, Ormia Region, Ethiopia. International Journal of Fisheries and Aquaculture. 2015;6(5):71-80

5. Girma Tilahun. Temporal Dynamics of the Species Composition, Abundance and Size- Fractionated Biomass and primary production of Phytoplankton in Lakes Ziway, Awassa and Chamo (Ethiopia). $\mathrm{PhD}$ Thesis Addis Ababa University, Addis Ababa. 2006;201.

6. Talling JF, Lemoalle J. Ecological dynamics of tropical inland waters Cambridge University Press, Cambridge. 1998.

7. Melack JM. Primary productivity and fish yields in tropical lakes. Trans Fish Soc. 1976a;105(5):575-580.

8. Hecky RE, Kilham P. Nutrient limitation in freshwater and marine environments: A review of recent evidence on the effects of enrichment Limnol.Oceanogr. 1988;33(4):796-822.

9. Hecky RE. The eutrophication of Lake Victoria. Verh Int Verein Limnol. 1993;25(1):39-48.

10. Kassahun A, Fekadu T, Zenebe T. Adaptability, growth and reproductive success of the Nile Tilapia, Oreochromisniloticus.(pisces: Cichlidae) stocked in Lake Tinshu Abaya (South Ethiopia). J Biol Sci. 2011;10(2):153-166.

11. Yirga E, Brook L. Zooplankton communities as indicator of ecosystem productivity in lake Tinishu Abaya, Rift Valley, Ethiopia. International Journal of Fisheries and aquaculture. 2018;10(5):53-70.

12. Yirga E, Brook L. Phytoplankton community composition and nutrien conditions as an indicator of ecosystem productivity in Lake Tinishu Abaya, rift valley, Ethiopia. International Journal of Fisheries and Aquatic Studies. 2018;6(3):173-186.

13. Yirga E, Brook L. Seasonality in the diet composition and ontogenetic dietary shifts of (Oreochromis Niloticus L.) (Pisces: Cichlidae) In Lake Tinishu Abaya, Ethiopia. International Journal of Fisheries and Aquatic Research. 2018;3(1):49-59.

14. Kalff J. Limnology: Inland water Ecosystems. Prentice- Hall, Inc, NJ. $2002 ; 592$.

15. Holmes JA. Seasonal Succession of Phytoplankton. Environmental Research and Teaching. Environmental Information Office, I. E. S, Toronto, 2000

16. American Public Health Association, APHA. Standard Methods for the Examination of Water and Wastewater. 19th ed. Washington, DC, USA; 1995.
17. Talling JF, Driver D. Some problems in estimation of terrestrial algae: The British Physiological Society, Cambridge Taxonomic analysis of the genus Anabaenopsis. Arch Hydrobiol. 1963;51:3-24.

18. Wetzel RG, Likens GE. Limnological analyses. 3rd ed. Verlag, New York, Inc. N.Y. 2000;429.

19. Olson FC. A system of morphometry. Hydrogr Rev. 1965;37:147-155.

20. Tadesse Fetahi. Plankton Communities and Ecology of Tropical Lakes Hayq and Awasa Ethiopia. Ph.D dissertation. Vienna University, 2010;98.

21. Margaleff R. Limnology Now: A Paradigm of Planetary Problems Elsevier, Amsterdam. 1996;220-222.

22. Brook Lemma. Changes in the limnological behavior of a tropical African explosion crater lake: L. Hora- Kilole, Ethiopia. Limnologica. 1994;24(1):57-70.

23. Baxter RM, Prossor MV, Talling JF, et al. Stratification in tropical African lakes at moderate altitudes (1500- 2000). Limnol Oceanogr. 1965;10(4):510-520.

24. Melack JM. Photosynthetic rates of four tropical African freshwaters Freshwat Biol. 1979a;9(6):555-571.

25. Goldman CT, Mason RD, Wood BJ. Light injury and inhibition in Antarctic freshwater phytoplankton. Limnol. Oceanogr. 1963;8(3):313322.

26. Beadle LC. The InlandWaters of TropicalAfrica.2nd ed. Longman Inc., New York. 1981. 457 p.

27. British Standards Institute (BSI). BSI Management of Public Swimming pools- Water Treatment Systems. Water Treatment Plant and Heating and Ventilation Systems Code of Practice. British Standards Institute, Publicly Available Specification (PAS) 39, 2003.

28. WHO. Guidelines for safe recreational water environments. Swimming pools and similar environments. Geneva, Switzerland; 2006.

29. Wetzel RG. Land- water interfaces: Metabolic and Limnological Regulations. Verb int ver Limno. 1990;24(1):6-24.

30. Girma Tilahun. A seasonal study on primary production in relation to light and nutrients in Lake Ziway, Ethiopia. M.Sc. Thesis, Addis Ababa University, Addis Ababa, 1988;62.

31. Demeke K, Amha B. Seasonal variation in phytoplankton primary production in relation to light and nutrients in Lake Awassa, Ethiopia. Hydrobiologia. 1990;196(3):217-227.

32. Tadesse Ogato. Dynamics of phytoplankton in relation to physicochemical factors in Lake Bishoftu, Ethiopia. MSc. Thesis, Addis Ababa University. $2007 ; 128$.

33. Melack JM. Photosynthetic activity of phytoplankton in tropical Africa Soda Lakes. Hydrobiologia. 1981;158:1-14.

34. Vareschi E. The Ecology of Lake Nakuru: Abiotic factors and primary production. Oecologia. 1982;55(1):81-101.

35. Melack JM, Kilham P. Photosynthetic activity of phytoplankton in tropical African Soda Lakes. Hydrobiologia. 1974a;81:71-85.

36. Melack JM, Kilham P. Photosynthetic rates of phytoplankton in East African alkaline saline lakes. Limnol Oceanogr. 1974b;19:743-755.

37. Wood RB, Talling JF. Chemical and algal relationships in salinity series of Ethiopian inland waters. Hydrobiologia. 1988;15(1):29-67.

38. Hecky RE, Kling H. The phytoplankton and protozooplankton of the euphotic zone of lake Tankanyika. Species composition, biomass, chlorophyll content and spatio- temporal distribution. Limnol Oceanogr. $1981 ; 26(3): 548-564$ 
39. Eyasu Shumbulo. The temporal and spatial variations in the biomass and photosynthetic production of phytoplankton in relation to some physicochemical variables in Lake Chamo Ethiopia. M.Sc.Thesis, Addis Ababa University, Addis Ababa. 2004;72.

40. Pentecost C, Happey- Wood CM. Primary production studies in two linked but contrasting Welsh lakes. Freshwat Biol. 1978;8:9-23.

41. Amarasinghe PB, Vijverberg J. Primary production in a tropical reservoir in Sri Lanka. Hydrobiologia. 2002;487(1):85- 93.

42. Smith VH. Light and nutrient effects on the relative biomass of blue-green algae in Lake Phytoplankton. Can J Fish Aquat Sci. 1986;43(1):148-153.

43. Ganf GG. Diurnal mixing and vertical distribution of phytoplankton in shallow equatorial lake (Lake George, Uganda). Ecology. 1974;62(2):611629.

44. Morris I. The physiological ecology of phytoplankton. Blackwell Scientific Publications. 1980;625.

45. Oduor SO, Schagerl M. Phytoplankton primary productivity characteristics in response to photosynthetically active radiation in three Kenyan rift valley saline-alkaline lakes. J Plankton Res. 2007b;19:10411050.
46. Melack JM. Photosynthetic activity of phytoplankton in tropical Africa Soda lakes1. Hydrobiologia. 1981;158:1-14.

47. Amha B, Wood RB. Primary production of five Ethiopian Rift Valley lakes. Verh Internat Limnol. 1984;22:1187-1192.

48. Getachew B, Seyoum M. Oligotrophication trend of Lake Ziway, Ethiopia. SINET: Ethiop J Sci. 2009;32(2):141-148.

49. Reynolds CS. The long, the short and the stalled: On the attributes of phytoplankton selected by physical mixing in lakes and rivers. Hydrobiologia. 1984;289(13):9-21.

50. Zinabu GM. Long-term changes in indices of chemical and productivity status of a group of tropical Ethiopian lakes, with differing exposure to human influence. Arch. Hydrobiologia. 1994;132(1):115-125.

51. Behrenfeld MJ, Prasil O, Kolber ZS, et al. Compensatory changes in PSII electron turnover rates protect photosynthesis from Photo inhibition. Photosynthesis Research. 1998;56:259-68. 